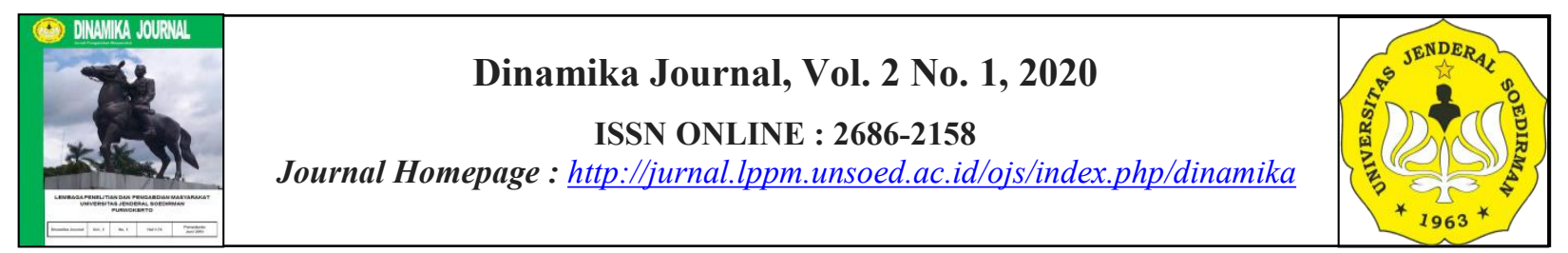

\title{
PENDAMPINGAN USAHA MAHASISWA DALAM BERWIRAUSAHA DI UNIVERSITAS JENDERAL SOEDIRMAN PURWOKERTO
}

\author{
Suryanto $^{1 *}$, Ekaningtyas Widiastuti ${ }^{2}$, Sugito $^{3}$ \\ ${ }^{1}$ Fakultas Ilmu-Ilmu Kesehatan, Universitas Jenderal Soedirman, Indonesia \\ ${ }^{2}$ Fakultas Ekonomi dan Bisnis, Universitas Jenderal Soedirman, Indonesia \\ ${ }^{3}$ Fakultas Matematika dan Ilmu Pengetahuan Alam, Universitas Jenderal Soedirman, \\ Indonesia \\ ${ }^{*}$ Corresponding author : soer_yanto4@yahoo.com \\ Received 27 September 2019; Accepted 28 February 2020; Available online 28 February 2020
}

\begin{abstract}
Abstrak
Program Mahasiswa Wirausaha di Universitas Jenderal Soedirman sudah berjalan sejak tahun 2011. Mahasiswa dilatih untuk belajar berwirausaha dengan diberi berbagai fasilitas seperti modal usaha yang bersifat hibah, pelatihan kewirausahaan dan pendampingan usaha. Mahasiswa diberi kesempatan untuk berlatih wirausaha dalam berbagai macam usaha seperti kuliner, berbagai macam budidaya, perdagangan dan lain-lain. Pendampingan usaha kepada kelompok usaha mahasiswa dilakukan oleh dosen yang ditunjuk dengan Surat Keputusan Rektor. Program kewirausahaan pada mahasiswa bertujuan untuk meningkatkan motivasi dan sikap berwirausaha mahasiswa Unsoed Purwokerto. Kegiatan pendampingan usaha dilakukan kepada kelompok-kelompok usaha yang berjumlah 27 kelompok, dengan jumlah peserta 81 mahasiswa. Pendampingan usaha dilakukan di kelas dan di tempat usaha. Pendampingan di kelas dilakukan dengan pemaparan hasil usaha yang telah dilakukan oleh kelompok usaha dan diskusi pemecahan masalah. Pendampingan di tempat usaha dilakukan dengan kunjungan lapangan secara langsung di tempat usaha para kelompok usaha. Ketua kelompok usaha menerangkan secara langsung proses produksi dan menyampaikan kendala dan permasalahan yang dialami saat produksi. Dosen pendamping melakukan diskusi dalam pemecahan masalah dengan kelompok usaha ditempat usaha. Pendampingan usaha kepada mahasiswa dalam melakukan wirausaha dapat meningkatkan motivasi dan sikap mahasiswa dalam bekerja menjalankan usaha.
\end{abstract}

Kata kunci : Pendampingan usaha, wirausaha, modal usaha, sikap kerja.

\begin{abstract}
The Entrepreneurial Student Program at Jenderal Soedirman University has been running since 2011. Students are trained to learn entrepreneurship by being provided with various facilities such as venture capital, grants, entrepreneurship training and business assistance. Students are given the opportunity to practice entrepreneurship in a variety of businesses such as culinary, various kinds of cultivation, trade and others. Business assistance for student business groups is carried out by lecturers appointed by the Chancellor's Decree. The entrepreneurship program for students aims to increase the motivation and
\end{abstract}


entrepreneurial attitudes of Unsoed Purwokerto students. Business assistance activities carried out to 27 business groups, with a total of 81 student participants. Business assistance is carried out in the classroom and at the place of business. Assistance in class is done by describing the results of the work that has been done by business groups and discussion of problem solving. Assistance at the place of business is carried out by direct field visits at the business places of the business groups. The head of the business group directly explains the production process and conveys the constraints and problems experienced during production. The accompanying lecturer conducts a discussion in solving problems with business groups in the business place. Business assistance for students in conducting entrepreneurship can improve students motivation and attitude in working to run a business.

Keyswords: Business assistance, entrepreneurship, venture capital, work attitude.

\section{PENDAHULUAN}

Pembelajaran berwirausaha memerlukan dukungan sikap yang kuat dari para pelaku wirausaha. Sikap pelaku usaha merupakan suatu pola perilaku atau kesiapan antisipatif, predisposisi untuk menyesuaikan diri dalam situasi sosial. Pelaku usaha harus mempunyai respon yang baik terhadap stimuli sosial yang telah terkondisikan. Pembentukan karakter kewirausahaan bisa terjadi di mana saja, salah satunya di Perguruan Tinggi. Institusi Perguruan Tinggi berperan penting dan berpeluang untuk menanamkan sikap mental kewirausahaan terhadap para mahasiswanya. Mahasiswa perlu diberi semangat untuk berwirausaha dan pemahaman mengenai kewirausahaan, agar tidak mengikuti fenomena umum (Yahya U dan Kristina S,2015). Faktor motivasi bagi mahasiswa wirausaha ada empat, yaitu capaian bisnis yang besar, faktor intrinsik, faktor kebebasan dan keamanan, serta faktor pendapatan. Faktor yang paling memotivasi mahasiswa dalam berwirausaha adalah faktor capaian bisnis yang besar. Dan peningkatan prestasi akademik mahasiswa wirausaha dipengaruhi oleh ketidakikutsertaan mahasiswa dalam kegiatan PKM-K (Ulfi $U$ dan Istiqlaliyah M,2017).

Mahasiswa Jurusan Akuntansi semester I cenderung kurang berminat berwirausaha, karena sebagian besar mahasiswa belum memahami wirausaha. Sikap, motivasi dan minat berwirausaha dipengaruhi ketidakpahaman menjalankan usaha (Rosmiati,et.al,2015). Disisi lain semakin tinggi kepuasan kerja maka semakin tinggi motivasi berprestasi dan sebaliknya semakin rendah kepuasan kerja maka semakin rendah motivasi berprestasi (Atica PW dan Eko D, 2013). Dan motivasi mahasiswa berwirausaha dengan ceramah, penugasan, pemutaran video tokoh wirausaha mengalami peningkatan yang signifikan sesudah pembelajaran sukses dan kegiatan brainstorming (Darpujianto, 2014).

Pendampingan usaha merupakan upaya untuk memberikan bimbingan, pengarahan dan sebagai media untuk memecahkan masalah yang dihadapi oleh kelompok usaha. Upaya pendampingan usaha penting dilakukan karena dapat memantau dan mengkontrol jalannya usaha. Disisi lain pendampingan usaha akan memberikan rasa percaya diri kelompok usaha dan meningkatkan motivasi serta sikap kerja dalam menjalankan usaha. Pendampingan usaha diperlukan untuk kelompok usaha yang baru menjalani usaha dan masih memerlukan pembinaan. Sejalan dengan bertambah mandirinya kelompok usaha maka kegiatan pendampingan usaha secara bertahap dapat dikurangi.

Hasil studi pendahuluan di Bagian Kemahasiswaan Unsoed diketahui bahwa pembelajaran kewirausahaan kepada para mahasiswa Universitas Jenderal Soedirman dilakukan secara kuliah di kelas dan dalam kegiatan ekstrakurikuler berupa Program Mahasiswa Wirausaha (PMW). Kegiatan PMW sudah berjalan sejak tahun 2011. Jumlah 
peserta PMW setiap tahun meningkat sekitar $10 \%$, peserta pada tiga tahun terakhir yaitu tahun 2015 sejumlah 103 kelompok, tahun 2016 sejumlah 114 kelompok dan tahun 2017 sejumlah 128 kelompok. Upaya untuk meningkatkan motivasi dan sikap kerja mahasiswa dalam berwirausaha perlu dilakukan pendampingan usaha. Kegiatan pengabdian ini bertujuan untuk meningkatkan motivasi dan sikap kerja mahasiswa dalam menjalankan kegiatan kewirausahaan di Universitas Jenderal Soedirman Purwokerto.

\section{METODE PELAKSANAAN}

Kegiatan pendampingan usaha merupakan salah satu pendekatan untuk membimbing dan mengarahkan serta membantu memecahkan masalah yang dihadapi oleh kelompok usaha. Kegiatan ini dilakukan dengan sasaran adalah mahasiswa Universitas Jenderal Soedirman yang menjadi peserta Program Mahasiswa Wirausaha (PMW) tahun 2019. Mitra kerja dalam kegiatan ini adalah Bagian Kemahasiswan dan Alumni Unsoed. Jumlah peserta (sasaran) adalah adalah 30 kelompok usaha dengan jumlah mahasiswa 87 orang. Lokasi tempat usaha berada di wilayah Purwokerto baik di tempat kos maupun di rumah sendiri. Data dikumpulkan dari sumber data primer yaitu para mahasiswa dengan teknik wawancara (interview) dan observasi dengan menggunakan lembar check list. Data sekunder dikumpulkan dari Bagian Kemahasiswan dan Alumni Unsoed dengan wawancara kepada petugas pengelola PMW dan studi dokumentasi.

Metode pendampingan usaha kepada kelompok usaha dilakukan dengan 2 (dua) rancangan kegiatan yaitu 1. Pendampingan di kelas (kampus) dan 2. Pendampingan di tempat usaha.

\subsection{Pendampingan di kelas (kampus)}

Kegiatan ini dilakukan di kelas atau kampus tempat Dosen Pendamping. Pendampingan usaha dilakukan sebelum para ketua kelompok usaha mencairkan modal usaha tahap I sebesar $80 \%$. Besar modal usaha setiap tim kelompok usaha berbeda-beda sesuai dengan anggaran di proposal yang telah setujui oleh Tim Reviewer PMW Unsoed. Setiap tim kelompok usaha secara bergantian menghadap Dosen Pendamping untuk melakukan bimbingan, diskusi dan konsultasi tentang Rencana Anggaran Belanja (RAB) setiap kelompok usaha. Setiap tim kelompok usaha dijelaskan teknik pencairan dana modal usaha tahap I yang dilakukan 2 kali yaitu $50 \%$ dan $50 \%$. Kelompok usaha yang sudah mencairkan dana 50\% dimotivasi untuk segera melakukan usaha dan melaporkan kegiatan usahanya kepada Dosen Pendamping. Tim kelompok usaha setelah melaporkan kemajuan usaha dari modal usaha yang 50\% kepada Dosen Pendamping diperkenankan untuk mencarikan dana modal usaha lagi sebanyak 50\% yang tersisa. Tim kelompok usaha yang sudah mencairkan dana $50 \%$ yang kedua kemudian melaporkan kemajuan usahanya. Laporan kemajuan usaha setiap tim kelompok usaha berisi berkas : Log book, Laporan kemajuan usaha, Laporan penggunaan dana modal usaha yang dilampiri dengan nota atau kwitansi dan contoh produk usaha. Langkah selanjutnya pendampingan usaha dilakukan dengan pemantauan usaha setiap 2 minggu sekali setiap tim kelompok usaha melaporkan kepada Dosen Pendamping dengan membawa log book. Pendampingan usaha di kelas yang terakhir adalah setiap ketua tim kelompok usaha memaparkan usaha yang telah dilakukan. Presentasi setiap kelompok usaha di hadapan Dosen Pendamping berlangsung selama 15 menit. Dosen Pendamping menilai dan memberikan masukan untuk setiap tim kelompok usaha. Hasil dari penilaian usaha yang telah dilakukan oleh semua tim kelompok usaha selanjutnya Dosen Pendamping merekomendasikan tim kelompok usaha yang telah berjalan dengan baik untuk menjadi peserta Expo I pada saat kegiatan Diesnatalis Unsoed di Gedung Graha Widyatama. 


\subsection{Pendampingan di lapangan (tempat usaha)}

Kegiatan pendampingan ini dilakukan oleh Dosen Pendamping langsung di tempat usaha setiap tim kelompok usaha. Tim kelompok usaha menerangkan kemajuan usaha dan menjelaskan kendala-kendala yang dihadapi. Pendampingan usaha ini juga langsung melihat hasil produksi setiap kelompok usaha sampai cara pemasaran produknya. Dosen Pendamping memberikan pengarahan dan menjadi fasilitator dalam pemecahan masalah yang dihadapi tim kelompok usaha. Hasil kegiatan pendampingan usaha di lapangan oleh Dosen Pendamping akan merekomendasikan kelompok untuk melakukan pengajuan proposal wirausaha di tahun berikutnya.

\section{HASIL DAN PEMBAHASAN}

Kegiatan pendampingan usaha dilakukan kepada sasaran yang berjumlah 30 tim kelompok usaha dengan jumlah mahasiswa 87 orang. Peserta (sasaran) kegiatan merupakan mahasiswa semester 2 dan 4 .

Tabel 1. Distribusi Frekwensi Sasaran Kegiatan Pendampingan Usaha

\begin{tabular}{llccc}
\hline No & Semester & $\begin{array}{c}\text { Frekuensi } \\
\text { (Orang) }\end{array}$ & $\begin{array}{c}\text { Presentase } \\
(\mathbf{\%})\end{array}$ \\
\hline 1 & II & & 32 & 36,8 \\
2 & IV & & 55 & 63,2 \\
\hline & & Total & $\mathbf{8 7}$ & $\mathbf{1 0 0 , 0}$ \\
\hline
\end{tabular}

Berdasarkan tabel diatas jumlah sasaran paling banyak adalah mahasiswa semester 4 yaitu sebanyak 55 orang $(63,3 \%)$.

Dari 87 mahasiswa terdapat beberapa mahasiswa yang berasal dari keluarga dan/atau anggota keluarga yang mempunyai latar belakang wirausaha. Distribusi frekwensi responden berdasarkan riwayat keluarga dan/atau anggota keluarga yang berlatar belakang wirausaha seperti pada tabel 2.

Tabel 2. Distribusi Frekwensi Sasaran Berdasarkan Latar Belakang Keluarga dan/atau Anggota Keluarga Yang Berwirausaha

\begin{tabular}{|c|c|c|c|}
\hline No & Latar Belakang berwirausaha & $\begin{array}{c}\text { Frekuensi } \\
\text { (Orang) }\end{array}$ & $\begin{array}{c}\text { Presentase } \\
(\%)\end{array}$ \\
\hline 1 & Ada & 61 & 70,11 \\
\hline 2 & Tidak & 26 & 29,89 \\
\hline & Total & 87 & 100,00 \\
\hline
\end{tabular}

Berdasarkan tabel diatas jumlah sasaran yang mempunyai riwayat keluarga berwirausaha sebanyak 61 orang $(70,11 \%)$. Dari 61 orang tersebut yang melakukan wirausaha meliputi orang tua (bapak dan/atau ibu) sebanyak 37 orang (60,7\%) dan sisanya adalah anggota keluarga lain (seperti: saudara, kakek, nenek) sejumlah 24 orang $(39,3 \%)$.

Hasil kegiatan pendampingan usaha di kelas pada tim kelompok usaha ditemukan beberapa kendala antara lain : kesibukan proses perkuliahan dan praktikum, komunikasi antar anggota kelompok dan masa liburan setelah ujian akhir semester. Terhadap kendala tersebut Dosen Pendamping memberikan saran dan menawarkan alternatif solusi pemecahan masalah antara lain : Kegiatan usaha dilakukan pada hari yang tidak ada jadwal kegiatan perkuliahan dan praktikum yaitu pada hari Sabtu dan Minggu. Cara pemasaran produk selain dijual langsung oleh mahasiswa dengan on line dan off line juga dapat dilakukan dengan sistem titip di beberapa kantin di setiap fakultas atau program studi. Mahasiswa bisa titip produk usahanya di kantin kampus di pagi hari sebelum kuliah dan diambil hasil penjualnya pada sore hari setelah kuliah. Permasalahan komunikasi antar anggota tim yang kurang karena anggota tim yang beda semester dan beda prodi dapat dilakukan dengan dibuat WhatApp 
Group (WAG) setiap tim kelompok usaha. Permasalahan libur akhir semester diberi alternative solusi dapat dilakukan dengan membuat produk usaha yang tidak banyak karena banyak mahasiswa yang libur dan sasaran pemasaran kepada pegawai, karyawan, dosen yang ada di kampus dan masyarakat umum.

Kendala pada saat pendampingan usaha di lapangan antara lain : peralatan yang belum lengkap dan tempat usaha yang sempit serta kerjasama anggota tim dalam proses produksi yang rendah karena kesibukan kegiatan perkuliahan dan praktikum. Alternatif solusi terkait peralatan yang masih belum lengkap agar memakai peralatan punya anggota tim dan peralatan yang belum tersedia bisa diusulkan untuk dibeli sesuai RAB dan bisa dilengkapi lagi pada RAB tahun kedua. Permasalahan tempat usaha yang sempit dapat dicari alternative solusi dengan cara menyewa tempat kos atau kios di sekitar kampus atau memakai rumah salah satu anggota tim yang mempunyai rumah luas. Permasalahan kerjasama yang rendah karena kesibukan kegiatan kuliah dan praktikum dapat dicari alternative solusi dengan melakukan usaha hari yang tidak ada kegiatan kuliah dan praktikum yaitu hari Sabtu dan Minggu

Kegiatan pendampingan usaha dapat meningkatkan motivasi kerja dan minat para mahasiswa dalam menjalankan kegiatan wirausaha. Minat berwirausaha pada mahasiswa berhubungan dengan motivasi pada diri mahasiswa yaitu adanya kebutuhan untuk berprestasi, kebutuhan kekuasaan dan kebutuhan berafiliasi. Mahasiswa sebagai insan manusia yang termasuk golongan berpendidikan sangat manusiawi apabila pada jiwa mahasiswa mempunyai ambisi untuk sukses dan bisa berprestasi dalam kehidupannya. Para mahasiswa dalam kehidupannya baik di lingkungan kampus maupun di masyarakat mempunyai kebutuhan untuk dihargai dalam hubungan dengan sosialnya. Mahasiswa dalam kehidupannya juga mempunyai kebutuhan untuk memperbanyak teman dan relasi baik di lingkungan kampus maupun di masyarakat. Oleh karena itu mahasiswa sangat aktif dalam kegiatan ekstra kurikuler di kampus. Keberhasilan dalam pemenuhan tiga kebutuhan tersebut akan menjadi dasar bagi mahasiswa dalam melakukan kegiatan kewirausahaan disamping kegiatan akademik lainnya.

Motivasi pada seseorang mahasiswa bersifat fluktuatif yaitu kadang-kadang tinggi namun pada suatu situasi dan kondisi lain juga bisa turun. Hal ini dapat dipengaruhi oleh faktor internal dan faktor eksternal. Faktor internal berasal dari dalam diri seperti adaya kemauan, kebutuhan, harapan, keinginan, idea atau gagasan dan lain-lainnya. Faktor eksternal berasal dari luar diri seseorang seperti adanya dukungan social dan situasi dan kondisi lingkungan. Dukungan social dapat berasal dari dorongan orang tua (bapak dan ibu), kakek, nenek, saudara, teman, sahabat, atasan atau pimpinan, dan lain-lain. Dukungan dari situasi dan kondisi lingkungan dapat berupa keeratan hubungan antara sesama mahasiswa, hubungan dengan dosen, hubungan dengan staf administrasi dan pimpinan. Dari faktor lingkungan juga bisa berasal dari kelengkapan peralatan kuliah, bahan dan alat praktikum, kerapian dan keindahan kampus, kebijakan pimpinan dan lain-lain.

Kewirausahaan pada seorang mahasiswa membutuhkan karakter dan kepribadian yang kuat pada seseorang. Seorang wirausahawan/wirausahawati perlu berjuang dengan sungguhsungguh sekuat tenaga, pantang menyerah, bersemangat, berani mengambil risiko dan kreatif. Potensi diri yang ada secara alami pada seseorang yang ada sejak lahir mungkin merupakan suatu talenta (bakat) merupakan modal dasar yang perlu diasah dan dikembangkan dengan proses pembelajaran agar bisa lebih bersinar dan memberikan harapan yang besar sehingga bisa sukses.

Mahasiswa dituntut kreatif dan inovatif dalam mengikuti proses pembelajaran (kuliah dan praktikum) maupun yang bersifat ekstrakurikuler berupa kewirausahaan, seni, olah raga dan lain-lain. Ahmad Esa, et.al, 2011 menyebutkan terdapat hubungan antara kegiaran ekstra 
kurikuler dan kokurikuler terhadap kemampuan seseorang dalam mengerjakan pekerjaannya sehari-hari. Sedangkan Shinta D,2012, menyebutkan pelatihan komunikasi efektif untuk meningkatkan efikasi diri pada keterampilan berkomunikasi para mahasiswa. Keterampilan berkomunikasi merupakan kebutuhan mahasiswa dalam kehidupan sehari-hari dan sebagai persiapan memasuki dunia kerja. Pelatihan harus dilakukan secara interaktif dan menarik.

Utomo H, 2010 menerangkan melihat realita secara jujur dan objektif, maka orang sadar bahwa menumbuhkan mental wirausaha merupakan terobosan yang penting dan tidak dapat ditunda-tunda lagi. Mahasiswa peserta wirausaha harus berpikir untuk melihat dan melangkah ke arah sana. Lembaga pendidikan melalui para praktisinya harus lebih konkret dalam menyiapkan program kegiatan pembelajaran yang benar-benar dapat mendorong tumbuh dan berkembangnya spirit kewirausahaan mulai dari sekolah dasar sampai perguruan tinggi.

Hasil kegiatan pendampingan usaha kepada tim kelompok usaha mendapatkan bahwa pemberian pengetahuan wirausaha kepada para mahasiswa di semua fakultas di Unsoed, baik jenjang Diploma III maupun Strata I dilakukan sesuai kurikulum dengan pemberian mata kuliah Kewirausahaan (KWU) yang penempatannya di semester III dan V. Pembekalan kewirausahaan diberikan juga pada kegiatan ekstrakurikuler yaitu Program Mahasiswa Wirausaha (PMW).

Strategi bisnis (usaha) yang dilakukan harus menampilkan perilaku yang baik, mempunyai pengetahuan dan keahlian usaha, mengutamakan produktivitas, mempunyai prinsip jual beli yang baik (tidak merugikan konsumen), menumbuhkan kepercayaan kepada pelanggan (konsumen), dan senantiasa memelihara sumberdaya yang terlibat (Suyanto, 2008).

\section{KESIMPULAN}

Kegiatan pendampingan usaha kepada para mahasiswa peserta Program Mahasiswa Wirausaha (PMW) menjadi suatu pendekatan yang tepat untuk membimbing, membina dan melatih mahasiswa dalam menjalankan usaha sesuai dengan bidang usaha yang dipilihnya. Kegiatan pendampingan usaha yang dilakukan oleh Dosen Pendamping dapat meningkatkan motivasi dan sikap kerja dalam menjalankan usaha masing-masing kelompok usaha.

\section{SARAN}

Tim kelompok usaha dan para mahasiswa peserta Program Mahasiswa Wirausaha (PMW) diharapkan untuk lebih dapat membagi waktu untuk mensinergikan kegiatan pembelajaran (kuliah dan praktikum) dengan kegiatan ekstrakurikuler di dalam kampus maupun di luar kampus.

\section{UCAPAN TERIMAKASIH}

Ucapan banyak terimakasih disampaikan kepada :

1. Ketua LPPM Unsoed beserta para staf atas kerjasamanya dalam pelaksanaan kegiatan Pengabdian Kepada Masyarakat ini.

2. Pimpinan Fikes Unsoed atas kerjasamanya dalam pelaksanaan kegiatan ini.

3. Para mahasiswa peserta Program Mahasiswa Wirausaha (PMW) Unsoed yang telah menjadi peserta (sasaran) kegiatan pendampingan usaha. 


\section{DAFTAR PUSTAKA}

Ahmad, E., Jailani, Md. Y., Aina, A. M. A. 2012. Developing soft skill in Advanced Technology Training Centre (ADTEC): an analysis of comparison, Journal Elixir Social Studies, 39 : 4895-49044.

As'ad, M. 2004. Psikologi Industri. Penerbit Liberty, Yogyakarta.

Atica, P.,W. Eko, D. 2013. Hubungan Antara Kepuasan Kerja dengan Motivasi Berprestasi pada Mahasiswa yang Bekerja Paruh Waktu. Jurnal Character, 1 (2).

Azwar, S. 2010. Sikap Manusia, Teori dan Pengukurannya. Penerbit Pustaka Pelajar, Yogyakarta.

Darpujianto. 2014. Pengaruh pembelajaran kewirausahaan terhadap motivasi berwirausaha pada mahasiswa STIE dan STMIK 'ASIA' MALANG. Jurnal JIBEKA, 08 (01) Februari 2014.

Jafrial, J., Edy, Y. 2014. 99 Detik Jadi Pengusaha. Penerbit PT. Elex Media Komputindo, Jakarta.

Kasmir. 2011. Kewirausahaan, Edisi Revisi. PT. Raja Grafindo Persada, Jakarta .

Notoatmodjo, S. 2012. Promosi Kesehatan dan Perilaku Kesehatan. Edisi revisi. Penerbit Rineka Cipta, Jakarta.

Retno, B. L., Trisnadi, W. 2012. Pengaruh Pendidikan Kewirausahaan Terhadap Minat Berwirausaha Mahasiswa di STIE MDP, STMIK MDP, dan STIE MUSI. Jurnal Ilmiah STIE MDP, 01 (02).

Riyan, M., Endang, S. A., Soe'oed, H. 2014. Pengaruh Keselamatan dan Kesehatan Kerja (K3) terhadap Motivasi dan Kinerja Karyawan. Jurnal Administrasi Bisnis (JAB), 9 (1).

Rosmiati, Donny, T. S. J., Munawar. 2015. Sikap, Motivasi dan Mnat Berwirausaha Mahasiswa. Jurnal Manajemen dan Kewirausahaan, 17 (01) : 21-30.

Shinta, Deta, K. W. 2012. Pengaruh Pelatihan Komunikasi Efektif Untuk Meningkatkan Efikasi Diri Mahasiswa. Jurnal Psikologi Pendidikan dan Perkembangan, 1 (02).

Suyanto, M. 2008. Muhammad Business Strategy and Ethics. Penerbit CV. Andi Offset, Yogyakarta.

Ulfi, U., Istiqlaliyah, M. 2017. Motivasi Berwirausaha, Manajemen Waktu, Manajemen Keuangan dan Prestasi Akademik pada Mahasiswa Wirausaha. Jurnal Ilmu Keluarga dan Konsumen, 10 (01) : 71-82.

Utomo, H. 2010. Kontribusi Soft Skill Dalam Menumbuhkan Jiwa Kewirausahaan. Jurnal Among Makarti, 3 (5).

Yahya, U., Kristina, S. 2015. Analisis Minat dan Motivasi Berwirausaha Mahasiswa (Studi pada Program Studi Administrasi Bisnis Telkom University Angkatan 2011). eProceeding of Management, 2 (3). 